\title{
Production, storage, and destination of seafood industry waste in five states of Brazil
}

\section{Produção, armazenagem e destinação do resíduo da industrialização de pescado em cinco estados brasileiros}

\author{
Werner Souza MARTINS ${ }^{1}$; Lia Ferraz de Arruda SUCASAS²; Ricardo BORGHESI ${ }^{3}$; Marília OETTERER ${ }^{2}$ \\ ${ }^{1}$ Universidade de São Paulo, Faculdade de Medicina Veterinária e Zootecnia, \\ Departamento de Medicina Veterinária Preventiva e Saúde Animal, São Paulo - SP, Brazil \\ ${ }^{2}$ Universidade de São Paulo, Escola Superior de Agricultura Luiz de Queiroz, \\ Departamento de Agroindústria, Alimentos e Nutrição, Piracicaba - SP, Brazil \\ ${ }^{3}$ Empresa Brasileira de Pesquisa Agropecuária (Embrapa), Embrapa Agropecuária Oeste, Dourados - MS, Brazil
}

\begin{abstract}
Large quantities of waste are generated throughout the seafood supply chain. Although this material has a great potential for use (e.g. pharmaceutical industry, animal feed production), if not managed properly it represents an environmental risk. In order to meet the volume, destination, and method of storage of waste of Brazilian seafood supply chain, we got information from 29 companies that have Official Veterinary Inspection (SIF). After the industrialization of seafood only $44 \%$ on average of the total raw material is used for human consumption and $59.2 \%$ of the unused portion is discarded in landfill.
\end{abstract}

Keywords: Seafood supply chain. Environment. Sustainability. Supply chain management.

\section{Resumo}

Grandes quantidades de resíduo são geradas ao longo da cadeia produtiva do pescado. Embora este material apresente um grande potencial de aproveitamento (e.g. indústria farmacêutica, produção de ração), se não for corretamente destinado, representa risco ambiental. A fim de conhecer o volume, a destinação e o método de armazenamento do resíduo produzido pela indústria do pescado no Brasil, 29 empresas de processamento de pescado, sob Serviço de Inspeção Federal (SIF), foram estudadas em todo o país. Identificou-se que cerca de $44 \%$ do total produzido é matériaprima utilizada para consumo humano, e 59,2\% representa resíduo sem finalidade útil, descartado em lixões.

Palavras-chave: Cadeia produtiva do pescado. Meio ambiente. Sustentabilidade. Gestão de cadeia produtiva.

Correspondence to:

Werner Souza Martins

Universidade de São Paulo, Faculdade de Medicina Veterinária

e Zootecnia, Departamento de Medicina Veterinária Preventiva

e Saúde Animal

Av. Prof. Dr. Orlando Marques de Paiva, 87

CEP 05508-270, São Paulo, SP, Brazil

e-mail:werner@usp.br

Received: $18 / 02 / 2017$

Approved: 27/07/2017

\section{Introduction}

Waste of food is an obstacle to the food security. The moral and ethic values around the food waste reduction are directly linked with questions like low income, limited resources of land, water and biodiversity, and the reduction of vulnerability (BAGHERZADEH et al., 2014).
According to Kristinsson and Rasco (2000) more than $50 \%$ of the remaining material from the total fish capture and aquaculture is not used, representing 79 million $\mathrm{t}^{-1}$ year (FAO, 2014a). The inappropriate disposal of waste causes a series of biological and chemical processes in the environment with potential impacts to aquatic and terrestrial ecosystems (LEITE et al., 2016). The seafood supply chain in Brazil is in development (FAO, 2014b), so there are still a number of challenges to overcome (OETTERER, 2002). Several studies have demonstrated that waste from the fish industry can be used as raw material for the production of silage, fertilizer, fishmeal, cosmetics, and medicines, among other things (ARRUDA et al., 2011; LEITE et al., 2016), generating resources for this production chain, maximizing profits, and minimizing costs. 
Countries like Australia, Finland, Germany, Korea, New Zealand, Scotland, and the USA have demonstrated interest in solving the problem of waste generation (BAGHERZADEH et al., 2014), and in Brazil very little information is available. The description and the investigation of the waste generation processes are fundamental to support applied research and development of technologies which promote and enable the use of this raw material, aiming at the sustainability of the supply chain.

Front the importance of this subject and the lack of specific literature, the aim of this research was at describing the destination of the waste and the methods of waste storage throughout production in Brazilian industries from the five top fishing states.

\section{Materials and Methods}

We used the list of companies under the Federal Inspection Service (SIF) of the Brazilian Ministry of Agricultural, Livestock, and Food Supply (Ministério da Agricultura, Pecuária e Abastecimento - MAPA) since these companies supposedly operate in a standardized manner (BRASIL, 1952).

Subsequently, the universe of the study was composed by five states with significant catches in 2010: Santa Catarina, Pará, Bahia, Maranhão, and Rio de Janeiro (BRASIL, 2010). The state of São Paulo was elected for the implementation of the pilot survey, in order to identify inconsistencies and make adjustments. Four companies were surveyed. The production from aquaculture was not considered.

The state of Santa Catarina has a large and diversified fishing fleet and is placed among Brazil's main seafood producers, fishing industrial production surpasses the artisanal fleet, representing $94 \%$ of the total landed, the industrial segment is predominant, especially for the Central-North coastal region (ANDRADE, 1998). The state of Santa Catarina is the leader in Brazilian fisheries according to the statistics (BRASIL, 2010).

In the state of Para the fishing activity is practiced in almost all municipalities, especially along the coast, and the fisheries are the main enterprises responsible for the economic development in most of these localities (BORCEM et al., 2012). In the year of 2009 they were responsible for $51.64 \%$ of the production in the North and $10.98 \%$ of the Brazilian production, being the second largest fish producer in the country, with 136.228 $\mathrm{t}$ (BRASIL, 2010).

In the state of Bahia fishing is mainly artisanal, exploring environments near the coast, because the boats are handcrafted, aiming at obtaining food, being partially intended for the market (BAHIA PESCA, 2017). In the year 2009 Bahia was the third state in fishing production $103.427 \mathrm{t}$ (BRASIL, 2010).

The state of Rio de Janeiro, which has occupied the first place in the production for the Brazilian extractive fishing, today places fourth with $56.643 \mathrm{t}$. The fishing fleet that operates along the coast of the state is made of vessels ranging from small to medium and large scale (BRASIL, 2010).

The structure of questionnaire (Figure 1) was based in the model used by (ALMEIDA et al., 2006). In order to develop and structuring the questionnaire, five meetings were held, each with an approximate duration of 90 minutes. Ten experts with training in the agrarian sciences, three experts from the seafood supply chain, and a moderator participated in the meetings, the principal issue (the waste generation by seafood supply chain) was discussed and the participants showed their opinions and considerations. This procedure is called focus group (MALHOTRA, 2012).

After the implementation of this pilot survey the questionnaire was adapted and hosted on the Internet page of the Research and Extension Group of Technological Innovation and Seafood Quality (GETEP/ESALQ/USP) ${ }^{1}$. This instrument enable companies to access and answer the questionnaire without identification, allowing the respondent to answer the questionnaire without a presence of researcher and a stipulated timeframe. This tool was available for a period of 90 days. The companies were instructed to access the web page on the Internet and answer the questionnaire. From March 2010 to June 2011 a total of 118 companies from the five states were invited, by phone and mail, to participate in the study (Table 1).

Data were collected, organized, and presented in figures and tables in accordance with the descriptive statistical analysis (QUIVY; VAN CAMPENHOUDT, 1998) and previous exploratory studies of the fisheries sector (ALMEIDA et al., 2006; STORI et al., 2006). The averages of the waste generation values, at different stages of production, were evaluated to identify if there was significant difference. The data were submitted to a normality test of Kolmogorov-Smirnov, and when showing normal distribution $(\mathrm{p}>0.05)$ they were submitted to variance analysis; those which did not show normal distribution were submitted to the Kruskal-Wallis test. The software SPSS version 20.0 was used.

\footnotetext{
http://www.lan.esalq.usp.br/getep/pesquisa/ciimar/index.html
} 


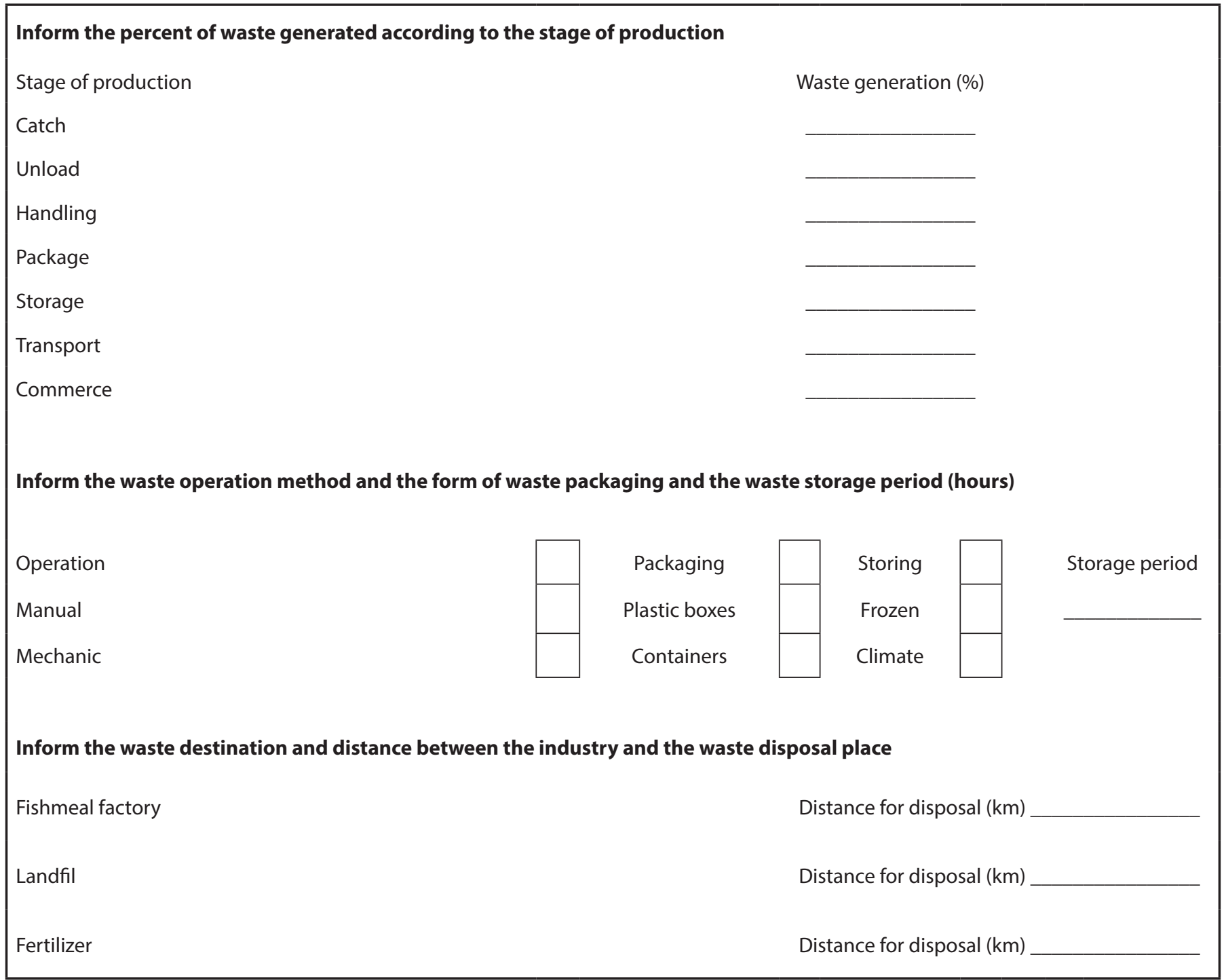

Figure 1 - Questionnaire used to collect the data - Department of Agri-food Industry, Food and Nutrition (LAN)/ESALQ/USP, Piracicaba (SP) - 2012

Table 1 - Warehouses of fish, which were enabled by the SIF - Department of Agri-food Industry, Food and Nutrition (LAN)/ ESALQ/USP, Piracicaba (SP) - 2012

\begin{tabular}{ccc}
\hline Pilot & Companies & Contacted companies \\
\hline São Paulo & 4 & 4 \\
TOTAL & 4 & 4 \\
Survey & & 26 \\
Santa Catarina & 59 & 22 \\
Pará & 31 & 0 \\
Maranhão & 1 & 3 \\
Bahia & 7 & 6 \\
Rio de Janeiro & 16 & 57 \\
TOTAL & 114 & 3 \\
\hline
\end{tabular}




\section{Results and Discussion}

The theme of this research is: "the generation of waste in the fishing industries of Brazil", which meets the requirements of scientific and social relevance (CINTRA, 1982), and has not been thoroughly explored in the academic context over the years.

Only 50\% of the 118 companies listed in the Federal Inspection Service in the category of warehouses could be contacted (Table 1). The reason for this is that the official list of contacts was outdated and many companies have changed their phone numbers or were no longer active.

Out of the 57 companies that were contacted, 25 (43\%) completed the questionnaire. A large number of previous studies used questionnaires for surveys in the fisheries sector with rates of return lower than the rates achieved in this study (SCHMITT; MAÇADA, 1997; ALMEIDA et al., 2006; STORI et al., 2006; CATCHPOLE; GRAY, 2010).

Waste production in relation to total of fish processed occurs at different stages throughout the seafood supply chain (Table 2). This value is the ratio of the total raw materials and total product processed that follows to the next link in the productive process. According to Pascoe (1997), Alverson and Hughes (1996), and Cathpole and Gray (2010) the waste generated in the seafood supply chain interferes in productive sustainability and the inappropriate disposal of waste reduces industrial profitability.

Table 2 - Waste generation according to the stage of production by region - Department of Agri-food Industry, Food and Nutrition (LAN)/ESALQ/USP, Piracicaba (SP) - 2012

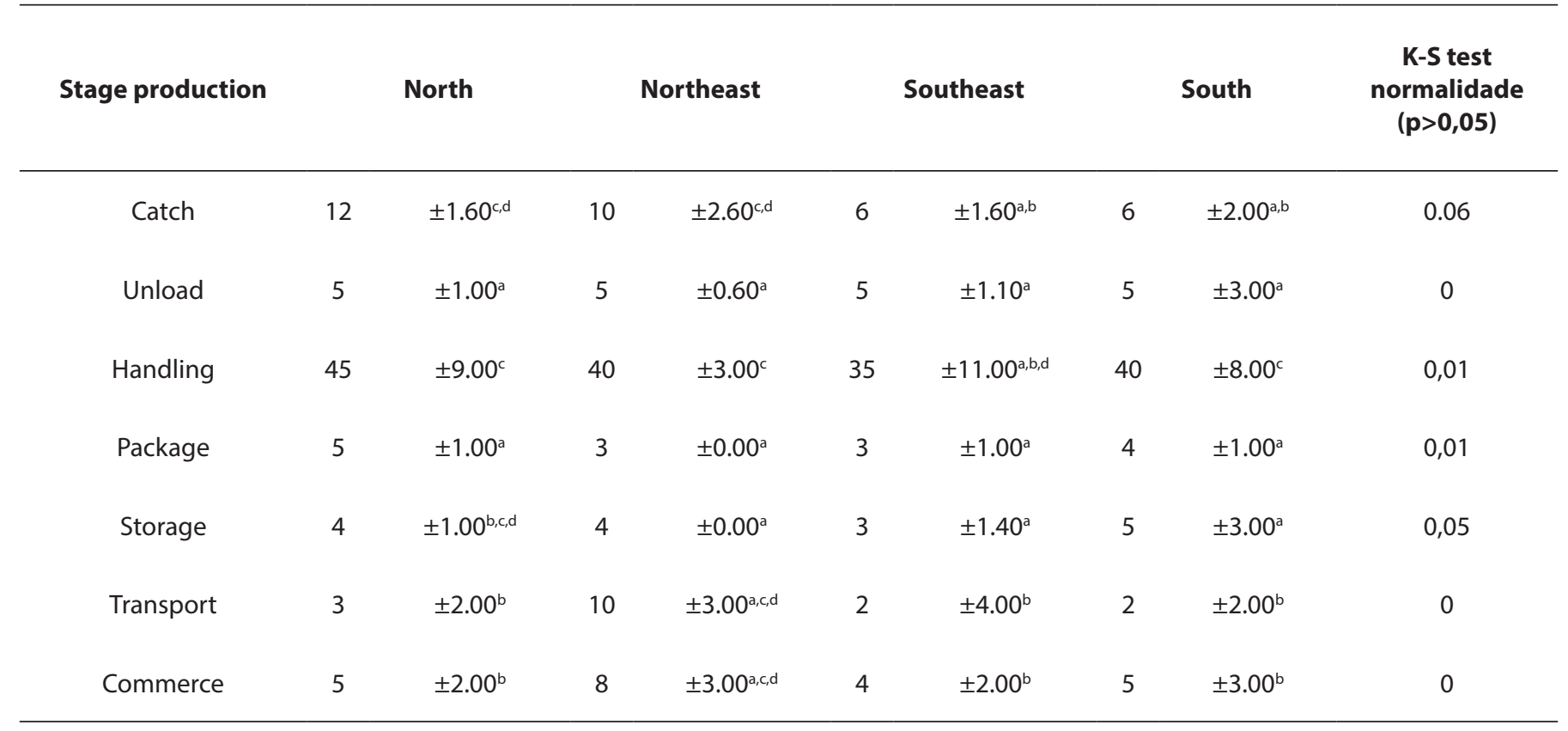

The energy expenditure for the fish production is high. According to Port et al. (2016), between 2003 and 2011, in Brazilian fisheries area the trawlers burned over 141.5 million liters of fuel. This energy consumption added to the consumption of 1000 kilocalories of energy for production of one kilocalorie of organic matter (ODUM, 2002) demonstrates the large consumption of energy to produce food from the sea and how noble this organic matter is. However, it is necessary that the supply chain, the consumers, and the Government be more concerned about the issue of sustainability. Extraction activities like fisheries and aquaculture (FAO, 2016) use raw material with high environmental cost (ADELIR-ALVES et al., 2016; SANTOS et al., 2017a), so they invest and use appropriate technology to extract the maximum performance (COMIN et al., 2016; CORRÊA et al., 2017; dos SANTOS et al., 2017b).

The new legal framework established by the recently approved Common Fisheries Policy of the European Union (EUROPEAN COMISSION, 2017) proposes the "maximum sustainable yield" (MSY) to exploitation of the stocks from 2015 (and at least from 2020) and the key for achieving this goal is the integral use of the natural resources. Several products have been obtained from waste such as chitin, chitosan, collagen, gelatine, polyunsaturated fatty acids $\omega-3$, taurine and creatine, antifreeze proteins, enzymes, chondroitin sulphate, fishmeal, and oil (LOPES 
et al., 2015). In Brazil the culture of sustainability is still recent and seldom practiced. The Regulation of Industrial Inspection for Products of Animal Origin (RIISPOA) (BRASIL, 2017) for the first time brought changes and now contemplates the subject of waste.

The generation of waste in the catch did not vary from the North-Northeast regions $(\mathrm{p}>0.05)$ and Southeast $(\mathrm{p}>0.05)$, but varied between the North and South, and the Northeast and South-Southeast (Table 2). According to Dias Neto and Dornelles (1996), there is a difference between the species diversity and the morphometric characteristics among species of the South and North. These income differences occur in industries of the same region (ALMEIDA et al., 2006). At different times of the year, mainly due to the reproductive biology of the species (MAULVAULT et al., 2012), there are changes in the weight and muscle of the fish and carcass yield (STORI et al., 2006). Storage in the Northern region presented significant difference $(p>0.05)$ from the other regions (Table 2). The Northern region presents a characteristic of operation harvest and storage, mainly of fish, for long periods. Storage at low temperatures causes water loss in muscle (OGAWA; MAIA, 1999; GONÇALVES et al., 2008; GONÇALVES; RIBEIRO, 2008; GONÇALVES, 2011). Trade and transportation in the Northeast showed a generation of waste with medium different from other regions $(\mathrm{p}>0.05)$ (Table 2). Regions with high temperatures influence the food loss in transportation and marketing in accordance with PEREIRA et al., (2010). The importance of monitoring and good use of cold chains and good practices are key elements to avoid losses in loads of fish (OETTERER, 2002; SOCCOL; OETTERER, 2003).

During fish processing, the waste is manually or mechanically handled by the companies. In the manual mode the waste is packaged in designated plastic boxes, which are differentiated from transport and storage boxes of fish by color. The boxes containing the residual material are periodically removed from local handling, chilled based on the specifications for this material and kept at the site until withdrawal and submission for processing or disposal. In the mechanical mode treadmills and worm screws are used to transport the waste to the tables for preparing them for the locations in which they will be wrapped and forwarded for disposal or processing (Table 3). According to Seibel and Souza-Soares (2003) in the industry the waste is of low quality. This waste is accumulated in tanks without receiving any type of treatment or proper management of material thrown, with separation of the edible parts and storage in acidic conditions would precede the preparation of silage in specialized industries and its use in animal feed.

Table 3 - Method of packaging and storage of waste Department of Agri-food Industry, Food and Nutrition (LAN)/ESALQ/USP, Piracicaba (SP) 2012

\begin{tabular}{ccccc}
\hline Operation & $\begin{array}{c}\text { Adopted \% } \\
\text { companies }\end{array}$ & Packaging & Storing & $\begin{array}{c}\text { Storage } \\
\text { period }\end{array}$ \\
\hline Manual & 90 & Plastic boxes & Frozen & $24 \mathrm{~h}$ \\
Mechanic & 10 & Containers & Climate & $10 \mathrm{~h}$ \\
\hline
\end{tabular}

According to Arvanitoyannis and Kassaveti (2008) the adequate managing of waste is important for the maintenance of the characteristics and enables many applications, such as animal feed, biodiesel/biogas, dietic products (chitosan), natural pigments (after extraction), food-packaging applications (chitosan), cosmetics (collagen), enzyme isolation, $\mathrm{Cr}$ immobilization, soil fertilization, and moisture maintenance in foods (hydrolysates).

According to Leite et al. (2016), the way the waste is packaged and conserved causes the proliferation of mesophilic and thermotolerant microorganisms eventually in levels above permitted by legislation. This prevents the use of waste to more useful purposes.

The transport of waste in the studied states occurs by road (Table 4). In the state of Para garbage trucks with a bucket volume of $32 \mathrm{~m}^{3}$ were used. In the state of Santa Catarina the mode of operation differs: the various companies use containers, trucks, and cranes. In the state of Rio de Janeiro we could not identify the residue collection and their processing in the fishmeal companies. The entire residue is transported to the city dump in Niteroi, RJ, for which garbage trucks with a bucket volume of $32 \mathrm{~m}^{3}$ were used.

This information shows that the recovery of waste does not cause an increase in the cost of production, since the cost of transferring the waste processing plants increases according to the distance of the place of disposal (MARTINS, 2011).

The fish waste is mainly protein source (LEITE et al., 2016) among other substances that are highly demanded by society. Alternatives to disposal have been presented, as 
the production of acidic silage (ARRUDA et al., 2011) and should be encouraged and promoted so that the seafood supply chain pass the act as other animal food chains already operate (MALONI; BROWN, 2006; YAKOVLEVA, 2007). There is a worldwide effort towards the development of technologies that minimize the production of waste from fishing (KIM; DEWAPRIYA, 2014; VENUGOPAL, 2016). The use of fish is still very low in the world, close to 50\% (MENON; LELE, 2015).

Table 4 - Waste destination and distance for disposal Department of Agri-food Industry, Food and Nutrition (LAN)/ESALQ/USP, Piracicaba (SP) 2012

\begin{tabular}{cccccc}
\hline & \multicolumn{2}{c}{ Waste destination (\%) } & \multicolumn{2}{c}{$\begin{array}{c}\text { Distance for } \\
\text { disposal }\end{array}$} \\
\cline { 2 - 6 } State & $\begin{array}{c}\text { Fishmeal } \\
\text { factory }\end{array}$ & Landfill & Fertiliser & $\begin{array}{c}\text { Fishmeal } \\
\text { factory }\end{array}$ & Landfill \\
\hline $\begin{array}{c}\text { Santa } \\
\text { Catarina }\end{array}$ & 72 & 25 & 3 & 191 & 22 \\
Pará & 27 & 62 & 11 & 222 & 43 \\
Bahia & 0 & 100 & 0 & 0 & 21 \\
$\begin{array}{c}\text { Rio de } \\
\text { Janeiro }\end{array}$ & 38 & 57 & 5 & 0 & 163 \\
Arithmetic \\
mean
\end{tabular}

There are numerous alternatives for the use of waste, as already mentioned, and research shows that there is a market for products derived from this raw material. Maximizing the use of fish biomass from fisheries is above all a change in culture. According to Oliveira et al. (2016), the global market for enzymes should grow on average $4.6 \%$ by 2020 and a promising source of collagenase is fish residue. The use of silage in aquaculture is proven to be a viable alternative (SOUZA et al., 2016), such as the utilization of fish waste as organic fertilization in agriculture (SOUSA et al., 2016) and consortium with vegetal fibers in the production of compost to agriculture. The possibilities are innumerable but it is necessary that the industries take interest in them.

In the coming years there will be requirements to the productive chains in order to operate cleanly and environmentally correctly (DENHAM et al., 2015), and this process is already taking place in countries such as the United States and Japan (THUY et al., 2014).

\section{Conclusion}

Good practices for storage and waste disposal should be implemented in all stages of the seafood supply chain. It is a commitment of the producer agent to give the best destination to aquaculture waste and all actors of the seafood supply chain should be oriented about the good practices.

If there is no appropriate place in the cities for the disposal of waste the fishing industries will not send the waste to other locations, and a shared responsibility program should be established between industries and municipal governments. There are no appropriate places to send the waste, and there is no demand for this material in four out of the five states researched. There was a lack of political will and low priority given to the destination of aquaculture residues, by both the federal and the municipal governments, as well as by the civil society.

Informing consumers about this issue is a way of increasing demand in relation to the industry and teaching the public to choose products made by industries that practice proper disposal of their waste and that have a sustainability interaction with society and the environment. Short-term changes in this scenario would be conquered through fiscal incentives aimed at developing changes in the industry culture, adjusting municipalities to waste treatment, and creating greater dialogue between industrial segments (e.g. fisheries and animal feed). In the long term the education of the society for a culture of sustainability and the effective application of the laws are the tools that Brazil has in order to advance in this scenario.

The amount of waste produced by the seafood supply chain justifies its use, contributing to the reduction of operating costs and maintaining the sustainability of the productive chain.

\section{Acknowledgements}

The authors received financial support for this study from the Foundation for the Coordination and Improvement of Higher Level or Education Personnel (Capes). 


\section{References}

ADELIR-ALVES, J.; ROCHA, G. R. A.; SOUZA, T. F.; PINHEIRO, P. C.; FREIRE, K. D. M. F. Abandoned, lost or otherwise discarded fishing gears in rocky reefs of Southern Brazil. Brazilian Journal of Oceanography, v. 64, n. 4 , p. $427-434,2016$. doi: 10.1590/s167987592016124806404 .

ALMEIDA, O.; AMARAL, L.; RIVERO, S. A mãode-obra da Indústria Pesqueira na Amazônia. Novos Cadernos NAEA, v. 9, n. 2, p. 5-24, 2006. doi: 10.5801/ ncn.v9i2.62.

ALVERSON, D. L.; HUGHES, S. E. Bycatch: from emotion to effective natural resource management. Reviews in Fish Biology and Fisheries, v. 6, n. 4, p. 443-462, 1996.

ANDRADE, H. A. Estrutura do setor industrial pesqueiro no Estado de Santa Catarina. Notas Técnicas Facimar, n. 2, p. 17-27, 1998.

ARRUDA, L. F.; MARTINS, P. E.; SILVA, A. F.; MORAES, J. E. R.; VAZ-PIRES, P.; OZORIO, R. O. D.; OETTERER, $M$. The fishery sector in portugal - report study. Boletim do Instituto de Pesca, v. 37, n. 2, p. 199-207, 2011. Available from: <http://bit.ly/2fevuk3>. Viewed: 21 Sept. 2017.

ARVANITOYANNIS, I. S.; KASSAVETI, A. Fish industry waste: treatments, environmental impacts, current and potential uses. International Journal of Food Science \& Technology, v. 43, n. 4, p. 726-745, 2008. doi: 10.1111/j.13652621.2006.01513.x.

BAGHERZADEH, M.; INAMURA, M.; H. JEONG. Food waste along the food chain. OECD Food, Agriculture and Fisheries Papers, n. 71, p. 1-28, 2014. doi: 10.1787/5jxrcmftzj36-en.

BAHIA PESCA. Pesca e aquicultura na Bahia. 2017. Available from: <http://www.bahiapesca.ba.gov.br/ modules/conteudo/conteudo.php?conteudo $=14>$. Viewed: 28 Sept. 2017.

BORCEM, E.; JÚNIOR, I.; ALMEIDA, I.; PALHETA, M.; PINTO, I. A atividade pesqueira no município de Marapanim-Pará, Brasil. Journal of Agricultural and Environmental Sciences, v. 54, n. 3, p. 189-201, 2012.
BRASIL. Câmara dos Deputados. Decreto-Lei no 30.691, de 29 de março de 1952. Aprova o novo Regulamento da Inspeção Industrial e Sanitária de Produtos de Origem Animal. Rio de Janeiro: Diário Oficial da União, 30 mar. 1952. Available from: <http://bit.ly/2hlcHHT $>$. Viewed: 21 Sept. 2017.

BRASIL. Ministério da Pesca e Aquicultura. Boletim estatístico da pesca e aquicultura. 2010. Available from: <http://bit.ly/2xlC28T>. Viewed: 21 Sept. 2017.

BRASIL. Ministério da Pesca e Aquicultura. Sistema de Informações Gerenciais do Serviço de Inspeção Federal. 2017. Available from: <http://bit.ly/2hmDpwu>. Viewed: 21 Sept. 2017.

CATCHPOLE, T. L.; GRAY, T. S. Reducing discards of fish at sea: a review of European pilot projects. Journal of Environmental Management, v. 91, n. 3, p. 717-723, 2010.

CINTRA, A. M. M. Determinação do tema de pesquisa. Ciência da Informação, v. 11, n. 2, p. 13-16, 1982. Available from: <http://bit.ly/2wK9vHW>. Viewed: 21 Sept. 2017.

COMIN, M.; DA COSTA, N. C.; DE QUADROS, D. A.; DE CASTRO, J. A. R.; FERREIRA, S. M.; DA SILVA, L. E. Caracterização biométrica e rendimento do filé e resíduos de pescados provenientes da pesca artesanal no município de Matinhos/PR. Cadernos de Agroecologia, v. 10, n. 3, 2016.

CORREAA, C. F.; TACHIBANA, L.; LEONARDO, A. F.; BACCARIN, A. E. Rendimento de carcaça, composição do filé e análise sensorial do robalo-peva de rio e de mar. Boletim do Instituto de Pesca, v. 39, n. 4, p. 401-410, 2017.

DENHAM, F. C.; HOWIESON, J. R.; SOLAH, V. A.; BISWAS, W. K. Environmental supply chain management in the seafood industry: past, present and future approaches. Journal of Cleaner Production, v. 90, p. 8290, 2015. doi: 10.1016/j.jclepro.2014.11.079.

DIAS NETO, J.; DORNELLES, L. D. C. Diagnóstico da pesca marítima do Brasil. Brasília, DF: IBAMA Instituto Brasileiro do Meio Ambiente e dos Recursos Naturais Renovaveis. 1996. 163 p. 
EUROPEAN COMISSION. Management of EU fisheries: What is the Common Fisheries Policy? 2017. Available from: $<$ https://ec.europa.eu/fisheries/cfp_en>. Viewed: 21 Sept. 2017.

FOOD AND AGRICULTURE ORGANIZATION OF THE UNITED NATIONS (FAO). The state of world fisheries and aquaculture: opportunities and challenges. Rome: FAO, 2014a. Available from: <http://bit.ly/1sLsLwl >. Viewed: 21 Sept. 2017.

FOOD AND AGRICULTURE ORGANIZATION OF THE UNITED NATIONS (FAO). World fish trade to set new records. Rome: FAO, 2014b. Available from: <http:// bit.ly/1f2yt4K>. Viewed: 21 Sept. 2017.

FOOD AND AGRICULTURE ORGANIZATION OF THE UNITED NATIONS (FAO). The state of world fisheries and aquaculture: contributing to food security and nutrition for all. Rome: FAO, 2016. Available from: <http:// http://www.fao.org/3/a-i5555e.pdf>. Viewed: 28 Sept. 2017.

GONÇALVES, A. A. Tecnologia do pescado: ciência, tecnologia, inovação e legislação. São Paulo: Atheneu, 2011. 608 p.

GONÇALVES, A. A.; RECH, B. T.; RODRIGUES, P. M.; PUCCI, D. M. T. Quality evaluation of frozen seafood (genypterus brasiliensis, prionotus punctatus, pleoticus muelleri and perna perna) previously treated with phosphates. Pan-American Journal of Aquatic Sciences, v. 3, n. 3, 2008.

GONÇALVES, A. A.; RIBEIRO, J. L. D. Do phosphates improve the seafood quality? Reality and legislation. PanAmerican Journal of Aquatic Sciences, v. 3, n. 3, 2008.

KIM, S. K.; DEWAPRIYA, P. Biologically active compounds form seafood processing by-products. In: BRAR, S. K.; DHILLON, G. S.; FERNANDES, M. (Eds.). Biotransformation of waste biomass into high value biochemicals. New York: Springer, 2014. p. 299-311.

KRISTINSSON, H. G.; RASCO, B. A. Fish protein hydrolysates: production, biochemical, and functional properties.Critical Reviewsin FoodScienceand Nutrition, v. 40, n. 1, p. 43-81, 2000. doi: 10.1080/10408690091189266.
LEITE, S. B. P.; SUCASAS, L. F. A.; OETTERER, M. Resíduos da comercialização de pescado marinho volume de descarte e aspectos microbiológicos. Revista Brasileira de Tecnologia Agroindustrial, v. 10, n. 1, p. 2112-2125, 2016. doi: 10.3895/rbta.v10n1.2692.

LOPES, C.; ANTELO, L. T.; FRANCO-URÍA, A.; ALONSO, A. A.; PÉREZ-MARTÍN, R. Valorisation of fish by-products against waste management treatments-Comparison of environmental impacts. Waste Management, v. 46, p. 103 112, 2015. doi: 10.1016/j.wasman.2015.08.017.

MAlHOTRA, N. K. Pesquisa de marketing: uma orientação aplicada. São Paulo: Bookman, 2012. 739 p.

MALONI, M. J.; BROWN, M. E. Corporate social responsibility in the supply chain: an application in the food industry. Journal of Business Ethics, v. 68, n. 1, p. 35-52, 2006. doi: 10.1007/s10551-006-9038-0.

MARTINS, W. S. Inquérito exploratório referente à geração, armazenamento, transporte e descarte de resíduos em indústrias de pesca do Brasil. 2011. 99 f. Dissertação (Mestrado em Ciência e Tecnologia de Alimentos) - Escola Superior de Agricultura "Luiz de Queiroz", Universidade de São Paulo, Piracicaba, 2011.

MAUlVAULT, A. L.; ANACLETO, P.; MACHADO, R.; AMARAL, A.; CARVALHO, M. L.; LOURENCO, H. M.; MARQUES, A. Effect of sex, maturation stage and cooking methods on the nutritional quality and safety of black scabbard fish (Aphanopus carbo Lowe, 1839). Journal of the Science of Food and Agriculture, v. 92, n. 7, 2012.

MENON, V. V.; LELE, S. S. Nutraceuticals and bioactive compounds from seafood processing waste. In: KIM, S. K. (Ed.). Springer handbook of marine biotechnology. New York: Springer, 2015. p. 1405-1425.

ODUM, H. T. Emergy accounting. In: Unveiling Wealth. Netherlands: Springer, 2002. 226 p.

OETTERER, M. Industrialização do pescado cultivado. Guaíba: Agropecuária, 2002. 200 p.

OGAWA, M.; MAIA, E. L. Manual de pesca: ciência e tecnologia do pescado. São Paulo: Varela, 1999. 430 p. 
OLIVEIRA, V. M.; CUNHA, M. N. C.; ASSIS, C. R. D.; NASCIMENTO, T. P.; HERCULANO, P. N.; CAVAlCANTI, M. T. H.; PORTO, A. L. F. Colagenases do pescado e suas aplicações industriais. Pubvet, v. 11, n. 3, p. 207-312, 2016. doi: 10.22256/pubvet.v11n3.243-255.

PASCOE, S. Bycatch management and the economics of discarding. Rome: FAO, 1997. 137 p.

PEREIRA, V. F.; DORIA, E. C. B.; JÚNIOR, B. D. C. C.; FILHO, L. D. C. N.; JÚNIOR, V. S. Avaliação de temperaturas em câmaras frigoríficas de transporte urbano de alimentos resfriados e congelados. Ciência e Tecnologia de Alimentos, v. 30, n. 1, p. 158-165, 2010.

POPPER, K. R. A lógica da pesquisa científica. São Paulo: Cultrix, 2004. 569 p.

PORT, D.; PEREZ, J. A. A.; DE MENEZES, J. T. Energy direct inputs and greenhouse gas emissions of the main industrial trawl fishery of Brazil. Marine Pollution Bulletin, v. 107, n. 1, p. 251-260, 2016. doi: 10.1016/j. marpolbul.2016.03.062.

QUIVY, R.; VAN CAMPENHOUDT, L. Manual de investigação em ciências sociais. Lisboa: Gradiva, 1998. 275 p.

SANTOS, L. C. M.; GASALLA, M. A.; DAHDOUHGUEBAS, F.; BITENCOURT, M. D. Socio-ecological assessment for environmental planning in coastal fishery areas: A case study in Brazilian mangroves. Ocean \& Coastal Management, v. 138, p. 60-69, 2017a. doi: 10.1016/j. ocecoaman.2017.01.009.

SANTOS, F. K.; VASCONCELOS FILHO, M. B.; DE SÁ VIEIRA, P. H.; MALHEIROS, L. S.; de OLIVEIRA FILHO, P. R. C. Rendimento corporal do saramunete, Pseudupeneus maculatus (BLOCH, 1793) submetido a diferentes métodos de filetagem. Arquivos de Ciências do Mar, v. 49, n. 2, p. 15-22, 2017 b.

SCHMITT, L.; MAÇADA, A. C. G. Competitividade e estratégia: o caso da indústria de pesca no Brasil. In: ENCONTRO NACIONAL DE ENGENHARIA DE PRODUÇÃO, 17., 1997, Gramado. Anais... Gramado: Enegep, 1997. p. 1-9.
SEIBEL, N. F.; SOUZA-SOARES, L. A. Produção de silagem química com resíduos de pescado marinho. Brazilian Journal of Food Technology, n. 150, 2003.

SOCCOL, M. C. S.; OETTERER, M. Use of modified atmosphere in seafood preservation. Brazilian Archives of Biology and Technology, v. 46, n. 4, p. 569-580, 2003. doi: 10.1590/S1516-89132003000400011.

SOUSA, W. L. D.; TEÓFILO, E. M.; FREITAS, J. B. S.; OLIVEIRA, A. L. T. D.; SOUSA, P. Z.; SALES, R. D. O. Aplicação do composto orgânico produzido a partir de resíduos de pescados e vegetais no cultivo do feijão caupi (Vignaunguiculata (L) walp). Revista Brasileira de Higiene e Sanidade Animal, v. 10, n. 2, p. 252-270, 2016. Available from: <http://bit.ly/2xlWrKN>. Viewed: 21 Sept. 2017.

SOUZA, J. M. L.; SALES, R. O.; AZEVEDO, A. R. Avaliação do ganho de biomassa de alevinos de tilápia (Oreochromis niloticus) alimentados com silagem biológica de resíduos de pescado. Revista Brasileira de Higiene e Sanidade Animal, v. 3, n. 1, p. 1-14, 2016. doi: 10.5935/1981-2965.20090001.

STORI, F. T.; BONILHA, L. E. C.; BARREIROS, M. A.; LACAVA, L.; PESSATTI, M. L. The organic solid residues of fish processing industries in Santa Catarina, Brazil: production scenaries and technologies. Journal of Coastal Research, v. 39, n. 3, p. 1793-1797, 2006. Available from: <http://bit.ly/2flvhPG>. Viewed: 22 Sept. 2017.

THUY, L. T. M.; OKAZAKI, E.; OSAKO, K. Isolation and characterization of acid-soluble collagen from the scales of marine fishes from Japan and Vietnam. Food Chemistry, v. 149, p. 264-270, 2014. doi: 10.1016/j. foodchem.2013.10.094.

VENUGOPAL, V. Chapter three - enzymes from seafood processing waste and their applications in seafood processing. Advances in Food and Nutrition Research, v. 78, p. 47-69, 2016. doi: 10.1016/bs.afnr.2016.06.004.

YAKOVLEVA, N. Measuring the sustainability of the food supply chain: a case study of the UK. Journal of Environmental Policy \& Planning, v. 9, n. 1, p. 75-100, 2007. doi: 10.1080/15239080701255005. 